\title{
THE LEGAL SERVICES COMMISSION - BRAVE NEW WORLD FOR LEGAL AID?
}

\section{David Capper, Reader in Law, Queen's University Belfast}

Further to the provisions of the Access to Justice (Northern Ireland) Order 2003 the Legal Services Commission for Northern Ireland took over responsibility (from the Law Society of Northern Ireland) for the operation of the Legal Aid Scheme on $1^{\text {st }}$ November 2003. Pursuant to two commencement orders, ${ }^{1}$ most of the operative provisions in articles 3-9 and Schedule 1 of the Order, relating to the establishment of the Commission, have now been brought into force. Other than that not much of the Order has been brought into force, one exception being article 12(8-11) under which the Lord Chancellor (now Secretary of State for Constitutional Affairs) may authorise the Commission to fund services otherwise excluded under Schedule 2. Other than article 12(8-11) nothing of articles 10-20 on civil legal services, and absolutely nothing of articles 21-31 on criminal defence services and Part III on conditional fees and litigation funding agreements, has been brought into force. It seems that for the time being it is intended that the Commission manages the current Legal Aid Scheme and moves gradually towards reform over the next few years.

Expectations of significant improvement in the management of the current Legal Aid Scheme may well be high. As successive reports of the Law Society, together with accompanying reports of the Lord Chancellor's Advisory Committee, have revealed, the quality of service delivered to practitioners and recipients of Legal Aid by the Legal Aid Department has left a lot to be desired. The Commission appointed by the Lord Chancellor is certainly a body of talented persons, with considerable management experience among them. It will have a huge job to do because the Commission has inherited the staff of the Legal Aid Department with all the culture of failure and other baggage brought along. It may have to be creative, proactive, and ruthless in implementing its agenda for an improved service, particularly with regard to setting and meeting considerably more rigorous targets for turning round applications for Legal Aid and the payment of fees.

The Order itself contains very few provisions of much interest. Most of its provisions confer wide powers on the Commission to operate, within boundaries set by the Department for Constitutional Affairs, a different Legal Aid Scheme from the one which has operated in this jurisdiction since 1965. In broad outline we can probably expect a fixed budget for Civil Legal Aid, divided into two separate sub-budgets, Civil Family and Civil Non-Family. There will almost certainly be a Funding Code to govern decisions as to when and for whom Legal Aid is to be provided. The Code will probably contain a broader and more holistic set of factors to take into account in

1 Access to Justice (NI) Order 2003 (Commencement No 1) Order (NI) 2003 (SR 2003/344); Access to Justice (NI) Order 2003 (Commencement No 2) Order (NI) 2003 (SR 2003/440). 
deciding whether to make Legal Aid available than is currently considered under the present merits' test. There will be no fixed budget for Criminal Legal Aid as human rights access to justice Article 6 European Convention arguments have prevailed against any such idea. Disappointingly the Order contains no specific steer towards the voluntary advice sector, although the Commission's general powers in articles 10-20 may allow for some initiatives to be introduced here in the future. The essential story of the Order is one of placing the current scheme under new (and hopefully better) management and giving the latter power to introduce reforms under the general supervision of the Department for Constitutional Affairs. Clearly much devil will be in the detail of the guidelines laid down by the Department, within which the Commission will have to operate.

Part III of the Order contains provisions relating to an area of major controversy over the last few years. This concerns the funding of personal injury actions. Readers may recall ${ }^{2}$ that a vigorous debate has been taking place as to whether conditional fee agreements (CFAs) should become the prime funding mechanism for these actions or whether there was any alternative that did not involve Legal Aid. The case for Legal Aid was put in this journal in the special issue devoted to "Access to Justice and Legal Aid Reform". ${ }^{3}$ The positive recommendation given to a Contingency Legal Aid Fund (CLAF) by the Legal Aid Advisory Committee ${ }^{4}$ is given a very firm "thumbs down" by articles 40-42 of the Order. Although "litigation funding agreements" are provided for by these provisions they depart so radically from the recommendations for a CLAF as to be completely unworkable. No "seed funding" will be provided from public funds, successful litigants would have to pay a portion of their damages into the fund, and costs would be generally recoverable against the fund by successful defendants. The Department for Constitutional Affairs is clinging on to its preferred option of CFAs through the provision made for them in articles 38-39. Whether these provisions are ever brought into force or whether the Commission will try to emulate Scotland by retaining personal injury actions within the Legal Aid Scheme, remains to be seen.

Some indication of what may happen in the short to medium term is provided by the Draft Implementation Plan for the Commission, to be discussed with the Commission on appointment. ${ }^{5}$ According to this during the first three years of the Commission's life preparatory work will begin on Civil Legal Services, the Funding Code, and the introduction of options for funding money recovery damages civil cases. A final decision on alternative funding mechanisms is not anticipated until 2005/2006. It is possible that the Commission may decide to concentrate on better management of the current

2 See (2002) 53 NILQ, No 2.

3 See D. Capper, "Personal Injury Litigation - The Case for Legal Aid" (2002) 53 NILQ 137

4 See Report of the Lord Chancellor's Advisory Committee in Northern Ireland, The Viability of Establishing a Contingency Legal Aid Fund or Conditional Fees in Northern Ireland (Northern Ireland Court Service, July 2001); D. Capper, "The Contingency Legal Aid Fund: A Third Way to Finance Personal Injury Litigation" (2003) 30 JLS 66

5 See

<http://www.legalservicescommissionni.gov.uk/draftimplementationplan.htm.> 
system for the time being and not explore alternatives very urgently until satisfied as to what the current system is capable of delivering. As was argued in this journal last year the current system has been so badly managed for so long that it may be impossible to tell what latent strengths it could possess should it be managed better. ${ }^{6}$ Amongst all the debate about reform it is possible that interested parties have failed to attach sufficient weight to the possibility that Legal Aid in Northern Ireland needs better management far more than it needs reform. This may not sound like a Brave New World but compared to what there has been for so many years it would be.

6 See Capper, supra $\mathrm{n} 2$. 